\title{
Fear of Crime among Women in the Old City Center of Istanbul
}

\author{
Funda Yirmibesoglu, Nilgun Ergun \\ Department of Urban and Regional Planning, Faculty of Architecture, Istanbul Technical University, Istanbul, \\ Turkey \\ Email: funday@itu.edu.tr, ergunn@itu.edu.tr
}

Received 14 May 2015; accepted 27 June 2015; published 30 June 2015

Copyright (C) 2015 by authors and Scientific Research Publishing Inc.

This work is licensed under the Creative Commons Attribution International License (CC BY). http://creativecommons.org/licenses/by/4.0/

(c) (i) Open Access

\begin{abstract}
Istanbul, the biggest city of Turkey with a population of $\mathbf{1 7}$ million people, is a city where both the negative and positive effects of urban life standards are intensely experienced. Along with problems such as migration from rural areas to urban areas, rapid population growth, unemployment and squatting, crime rates have recently been observed to go higher (Yirmibesoğlu \& Ergun, 2013). The old city center, Beyoglu was infamously known for its high crime rates and fear of crime, but today it seems that this image has changed and the fear of crime has decreased. Among the reasons for this decrease, we can mention the fact that Beyoglu has been through a gentrification process that some buildings have been restored, and that urban design implementations have been done in some streets. This study aimed to find out how fear of crime according to gender differed before and after the renovation process. With this aim in mind, field research and surveys were conducted in 2006 and 2010 . The research problem, fear of crime and environmental safety in Beyoglu, was investigated based on certain variables such as the participants' gender, occupation, duration of residence in Istanbul, the place of residence, age group, place of birth, and educational level; the participants were also asked about the frequency of their visits to Beyoglu and the reasons why they go to Beyoglu. The results of the study revealed the differences in fear of crime between men and women. It was found that Beyoglu district became safer after the renovations; yet, the rate of fear of walking alone, and therefore the fear of crime, was found to be higher among women than among men.
\end{abstract}

\section{Keywords}

Crime, Women, Fear, City Center, Istanbul

\section{Introduction}

Istanbul has a segmented structure both in terms of its land use and the socio-economic levels of its residential 
areas. Differences in physical structure, such as the division of the city by Bosphorus, multi-centered urban development, and scattered, unplanned housing areas (squatter areas) in the city are reflected in the distribution of crime rates.

Crime rates are higher in the districts that are older and closer to the center and lower in districts established as a result of migration from rural areas (Ergun \& Yirmibesoglu, 2007).

The residential population in the center of Beyogluis low but daily population is very high, and this district has the highest functional load and also has different user quality, quantity, and diversity. It is observed that the social control mechanisms are at a lower level in these areas where the majority of land use is allocated to business (Yirmibesoglu \& Ergun, 2013).

Wilson and Kelling (1982) focused on the phenomena of "broken windows". They arguethat residents will be less likely to get involved in situations in which help is needed if social and physical incivilities make residents fearful. If residents become less vigilant and less action-oriented, capacities for local social control will erode. As a result, the area will become “vulnerable to criminal invasion”. Graphically, Wilson and Kelling (1982) propose the following casual sequence:

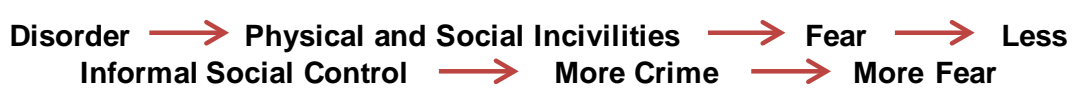

The argument is that physical changes in environment such as increased dilapidation through cognitive effects on fear levels and behavioral effects on informal social control will lead to criminal invasion and higher crime levels. This suggests that, as a crime prevention strategy, major physical improvements such as renovating rundown housing, razing or restoring abandoned housing, cleaning up of playgrounds and public areas, and strict enforcement of housing codes will lower fear levels, thereby increasing levels of informal social control and decreasing the chance of invasion from outside offenders (Taylor \& Gottfredson, 1987).

In the old city center Beyoglu, which has a high crime rate and which shares similarities with the city centers in research conducted by the most prominent theoreticians of crime (Shaw \& McKay, 1942; Park \& Burgess, 1924), the number of crimes and the fear of crime has recently been observed to decrease (Yirmibesoglu \& Ergun, 2013, 2007). Among the reasons for this decrease are that the district has undergone a gentrification process, that some buildings have been restored, and that urban design implementations have been carried out in some streets (Ergun, 2004).

This study focused on how fear of crime according to gender differed before and after the renovation process and it examined whether or not there were differences between men and women in terms of their perceptions of safety of the district based on the participants' occupation, age, educational level, place of birth, duration of residence in Istanbul, and the current place of residence.

\section{Fear of Crime and Gender}

Reducing fear of crime, as well as preventing or reducing crime, is one of the most important steps to take in order to create healthy living environments since the problem is not all about crime itself, but also about fear of crime. Schweitzer et al. (1999) posits that crime in the United States cannot be eliminated although there has been a decrease in crime since 1994 and adds that crime is a fact of life and what affects people is fear of crime rather than actual crime.

Research has revealed that there is a difference between the actual amount of crime and the perceived amount of crime and that perception is always stronger than reality. Fear of crime keeps growing unless taken under control. The growth of fear of crime is triggered by environmental factors such as thrash, graffiti, noise, abandoned buildings, and damaged cars, antisocial behaviors such as gangs or being drunk and rowdy, distrust toward the police, bad reputation of urban areas due to crime, and the severity of criminal attacks in those areas (Taylor \& Covington, 1993; McCrea et al., 2005).

Research has shown that fear of crime may change from country to country and according to the country's sociocultural and political-institutional structure (Hirtenlehner \& Farrall, 2013), and that crime and fear of crime is correlated with individuals' education level, income level, race, age, duration of residence, sense of belonging to the place of residence, and most of all with their gender (Gray, Jackson, \& Farrall, 2011). MacMillan et al. (2000), McCrea et al. (2005), and Pain (1997) found that women fear crime at higher levels than men. Similar 
studies on this topic are explained below.

Gilchrist et al. (1998) conducted a study to determine the different rates of fear of crime among men and women. Professional empirically generated survey data about the fear of crime persistently indicate relatively small but statistically significant differences between fear rates expressed by men and women. Such differences are contrasted with objective crime victimization risk ratios; regularly magnified by amateur surveys; and have been ossified as stereotypes by the media. Subsequently, all women are believed to be fearful of crime, and all men fearless. The research reported herein encountered, paradoxically, fearful men and fearless women. A dissection of their qualitatively garnered feelings indicates, in a very provisional way, the general conditions under which crime-related fears are reduced and enhanced.

Chui et al.'s (2013) study investigated fear of crime in a group of students in Hong Kong; using a sample of 170 Hong Kong college students majoring in social work, the study aimed to investigate the effects of gender on fear of crime and their relationships to attitudes toward prisoners. In general, women reported a significantly greater fear of crime than men for all offenses except for being cheated. Fear of rape/sexual assault was found to be a significant predictor of fear of serious crimes for women but a less significant predictor of their fear of minor crimes. The shadow of the sexual assault hypothesis was supported in this study. Fear of crime had little impact on attitudes toward prisoners.

In their study on fear of crime in Stockholm, Smith and Torstensson (1997) state that "women and elderly are most fearful is a central paradox in the fear of crime literature". Four attempts to resolve the paradox are discussed: hidden victimization of women; greater tendencies of women to recall early life-course experiences, and to generalize fear from one context to another and from one type of victimization to another; vulnerability of women; and male discounting of fear. Empirical evidence from a Stockholm survey is used to argue that the hidden victimization stratagem does not seem likely to succeed in explaining fear levels. Tendencies for women to generalize differently from men across time, space or type of victimization experience are not found or weak. Results are consistent with the vulnerability hypothesis, specifically the greater "ecological vulnerability" of women (Sparks, 1982), but there is also evidence of male "discounting" of risk and fear. Further research is needed to assess the extent to which female vulnerability is more important than male discounting in accounting for risk perceptions and fear of crime.

In their study, conducted in the United Kingdom, Rengifo and Bolton (2012) examined individual-level associations between fear of crime and various environmental and cognitive assessments but have largely dismissed the relationship between various dimensions of fear and broad behavioral adaptations. Drawing on the risk interpretation model, we specify path models to assess the nature of relationships between perceptions of risk of crime and disorder and the patterning of voluntary and compulsory routine activities. They also explore whether these activities influence the relationship between disorder, risk and fear. Using data from the 2007 and 2008 British Crime Survey, they find support for the proposed distinction between types of routine activities. Although they also find that the various manifestations of fear exhibit different associations with these activities, their models offer marginal support for the proposed mediating role of behavioral policies.

Many studies on crime suggest that certain crimes, fear of crime and the feeling of distrust can be reduced through a better design of built-up environments and regular maintenance. This approach is known as crime prevention through environmental design in the United States, Canada, and Australia. In Europe, this concept is also known as "the reduction of crime and fear of crime by urban planning and building design".

The aim of the present study, similar to the studies conducted in other countries, is to explore to what extent gender is relevant in fear of crime. To that end, this study examines fear of crime among women in Beyoglu, the old city center of Istanbul, in 2006 and 2010 and investigates the changes in the levels of fear of crime after the renovation implementations in the area.

\section{Fear of Crime among Women in Beyoglu}

Beyoglu is one of the oldest settlements in Istanbul's European side in the Marmara Region, Turkey. The area of Beyoglu is $8.76 \mathrm{~km}^{2}$, consisting of 45 quarters. According to 2012 address-based population registration system (TUIK, 2012), Beyogluhas a population of 246,152 and female population $(120,169)$ is less than male population (Table 1, Map 1). Beyoglu is a distinctive settlement, especially considering the fact that its population reaches millions during the day and night (TUIK, 2012; Yirmibesoglu \& Ergun, 2013).

According to data (IPD, 2008) obtained from the Istanbul Police Department, personal and property crime declined in Beyoglu district, especially in 2007 (Figure 1). 
Table 1. The population of Beyoglu in 2012.

\begin{tabular}{cc}
\hline 2012 Population & City/Town Center \\
\hline Female & 120,169 \\
Male & 125,983 \\
Total & 246,152 \\
\hline
\end{tabular}

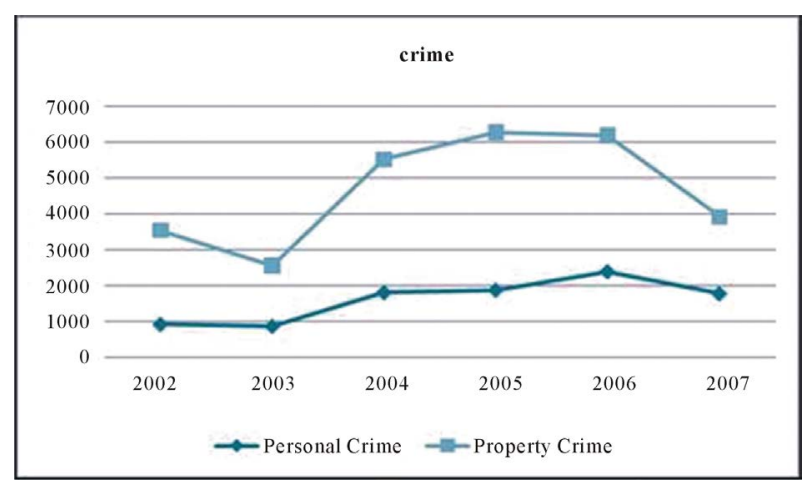

Figure 1. Crime against property and person.

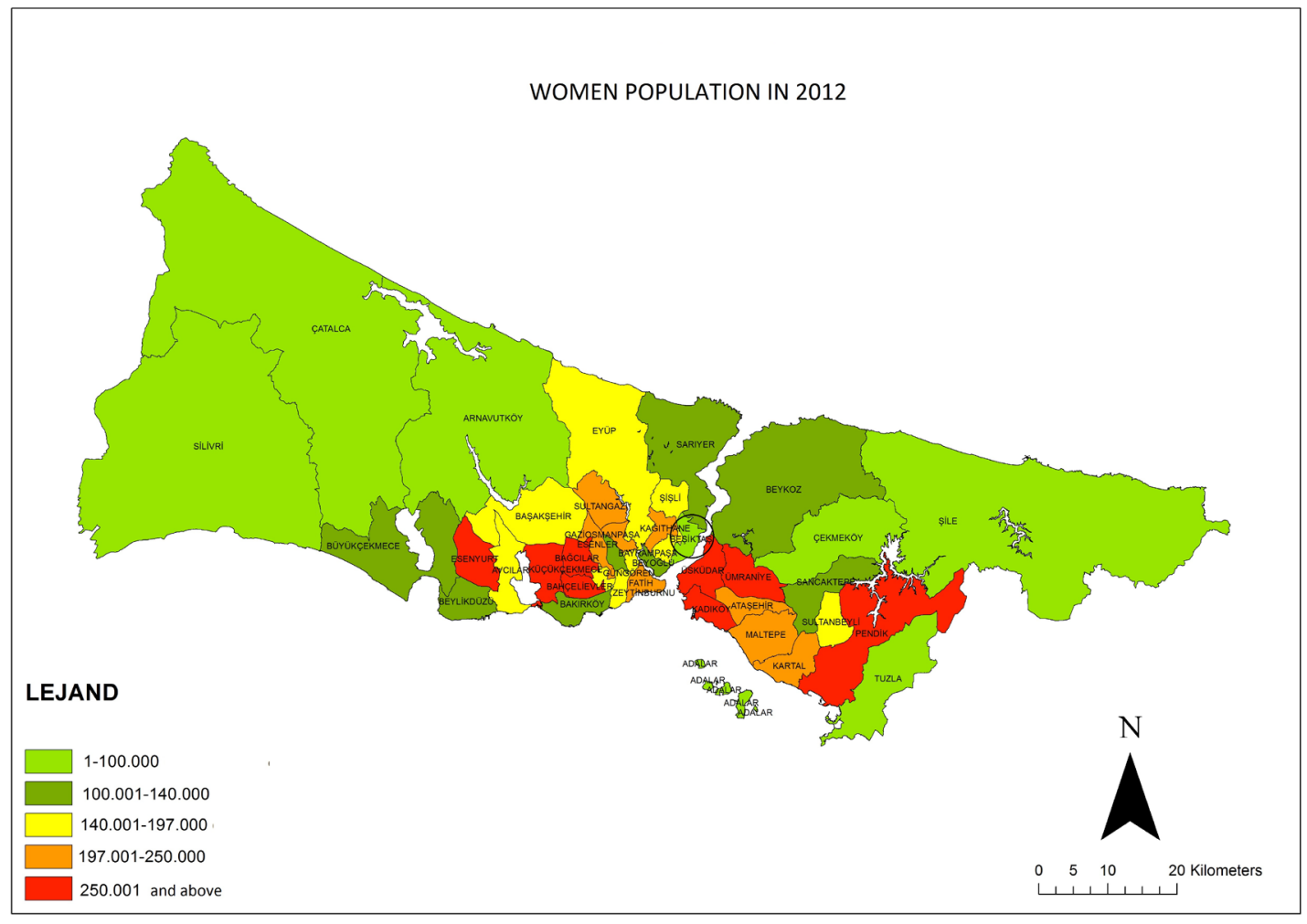

Map 1. The distribution of female population in Beyoglu district and İstanbul in 2012. Source: Berkoz et al., 2013.

As these changes were taking place, a sharp increase in property crime was observed because of the fact that wealthier people were entering the area in the 2000s. As from 2004, an analysis concerning crime in Beyoglu district was conducted, showing that during the first periods, burglaries and extortion occurred more frequently; crimes against the person transpired more in and around bars or similar venues, related to alcohol and drugs. If 
the interventions made in this period are analyzed, it can be seen that; the street, square and historical building lighting process that started in 2004 and completed in 2006, a major campaign against drugs and thief gangs, have been implemented; surveillance cameras have been installed; moreover, restoration of old public buildings in the area have begun, together with construction of new buildings (Yirmibesoglu \& Ergun, 2013).

The district became a residential area not only for Anatolian emigrants because of its central location and its being one of the oldest districts in Istanbul, but also for foreign immigrants from Africa and Central Asia. Thanks to a law that came into effect in 2004, renewals in historical locations have begun and the people who live here and who are seen as the major cause of crimes were removed and evicted.

In order to explore the fear of crime in the Beyoglu district, a total of 300 surveys (100 surveys per neighborhood) have been conducted on the users of the area in Cihangir, Asmali Mescit and Galata neighborhoods, all of which were recently renovated in 2006 (Figure 2). This survey was repeated in 2010 in order to present the change in fear of crime. The rates of females interviewed in 2006 and 2010 are close to each other (approximately 43\% - 44\%) (Appendix 1).

As far as educational backgrounds are concerned, persons who participated in the survey in 2006, have a high educational level (43\% high school, 30.3\% university). In 2010, these levels are found to be decreasing (29\% university) and increasing (48\% high school).

Regarding the age groups of the survey participants, the majority of the female users of Beyoglu fall into the 21 - 30 age group and the majority of male users into the 31 - 40 age group.

As for occupational groups, 2006 data shows us that the highest rate (29.3\%) belongs to scientific and technical self-employed professionals. Commerce and sales professionals are second at $16.7 \%$. Employees of the service sector turn out at $15.3 \%$ and non-agricultural employees at $11.7 \%$. It is seen that the rate of students increased in 2010 (25.7\%).

As for where the participants of the survey live in Istanbul, 2006 statistics show us that the rate of people living in city centers is considerably high at $46.7 \%$. In 2010 , this rate decreases to $18.3 \%$. It is regarded that the rate of people who live in city centers or within $10 \mathrm{~km}$ of city centers is high $(76.4 \%$ and $65.0 \%$ by order of survey years) (Figure 3 ).

According to the 2006 statistics, when the duration of residence in Istanbul is considered, the rate of new arrivals ( 0 - 5 years) turns out very low, 13.7\%. In 2010 this rate increases to $21.3 \%$. According to 2006 statistics, the rate of residence for 10 years or more is 73\%, and approximately 63\% in 2010 (Appendix 2).

The participants' weekly use of Beyoglu appears to be quite frequent. In 2006, maximum $46 \%$ visited Beyoglu daily. In 2010, this level is found to be decreasing to 26.3\% (Figure 4).

Regarding the rate of women who use Beyoglu daily, in 2006 the rate is $17.7 \%$, whereas it decreases to be $4.3 \%$ in 2010.

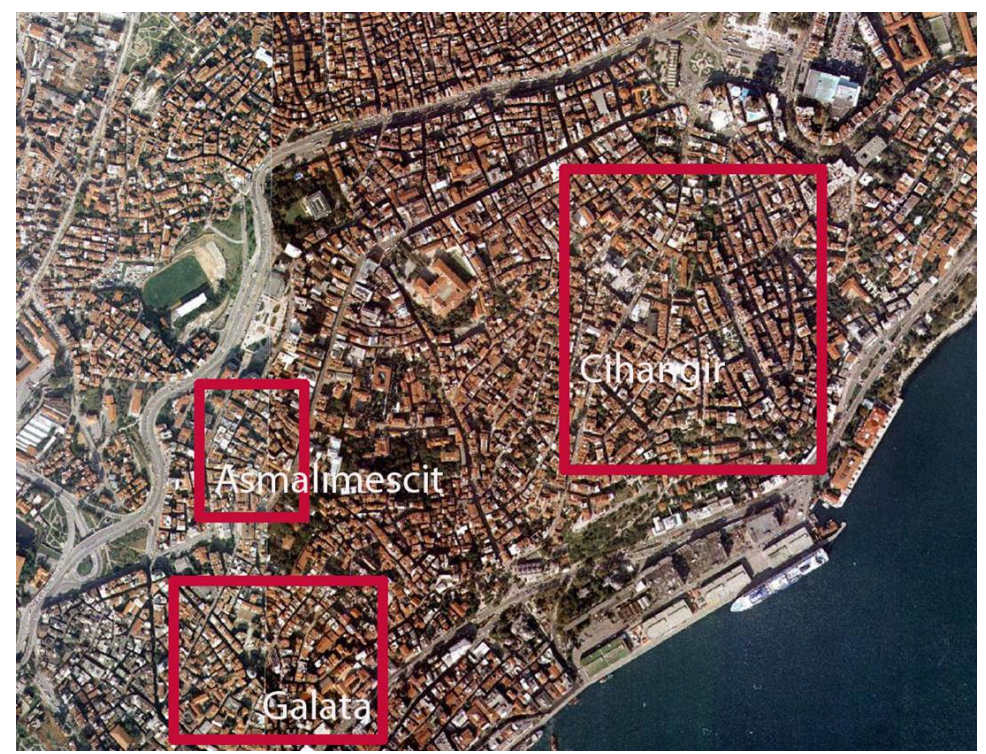

Figure 2. Cihangir, Asmalı Mescit and Galata neighborhoods in Beyoglu. 


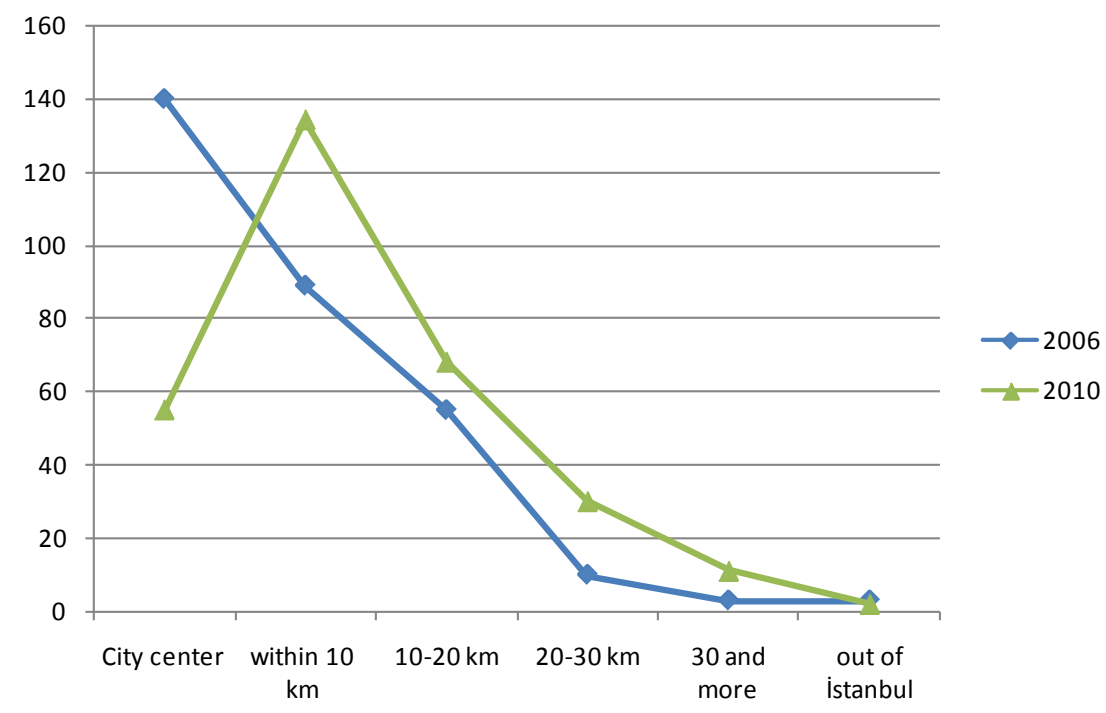

Figure 3. Participants’ place of residence.

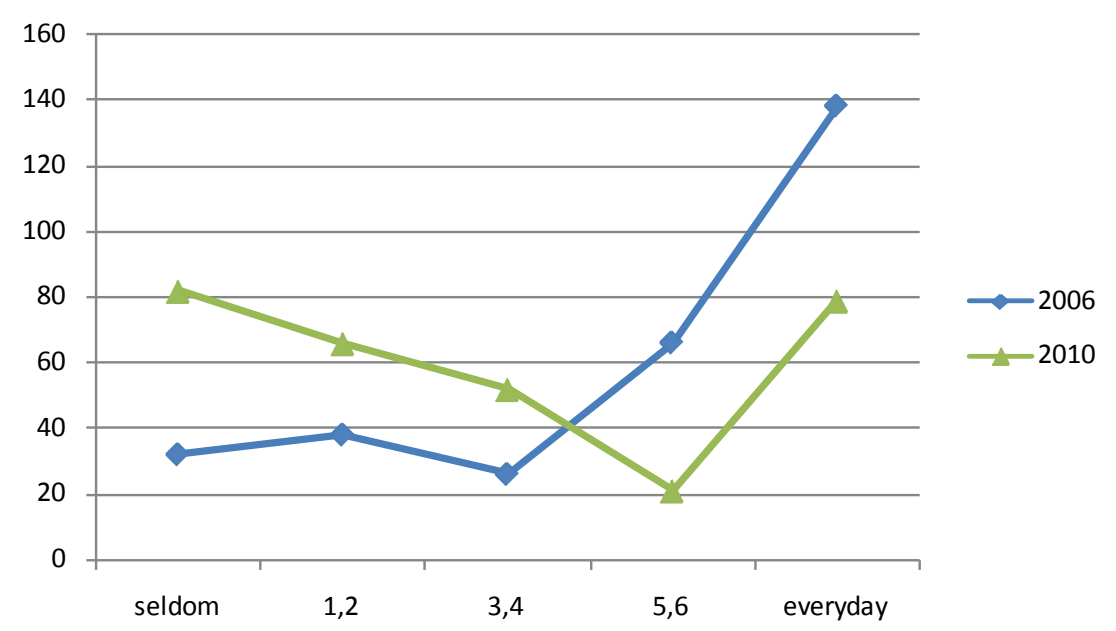

Figure 4. Weekly use of Beyoglu.

Regarding the reasons why participants come to Beyoglu, it appears that a high rate of participants (37.3\%) comes for residence in 2006.The rate of people who came to Beyoglu for entertainment and shopping purposes in 2010 is $63.0 \%$. As can be seen in the table, in 2010 the reasons why women come to Beyoglu seem to be entertainment and shopping (37\%), but the rate of women who come to Beyoglu for the same purposes in 2006 is $17 \%$. It is observed that men come to Beyoglu mostly for business purposes (20\% and 26\%) (Appendix 3).

Concerning daytime safety in Beyoglu, most of the participants state that Beyoglu is safe during the day. It is observed to be $69.7 \%$ and $79.7 \%$ safe in the two surveys, respectively (Table 2). While the rate of women who state that the district is safe during daytime is $28 \%$ in 2006, it is $36 \%$ in 2010 .

As far as nighttime safety in Beyoglu is concerned, a very large number of the participants state that Beyoglu is not safe at nights. Beyoglu is considered safe at a rate of $24.7 \%$ and $47.3 \%$ in the two surveys, respectively. While the rate of participants who report that Beyoglu is safe during nighttime was 7\% in 2006, it increases to be $15.3 \%$ in 2010 .

Considering if people are afraid of walking alone in Beyoglu, most of the participants state that they are not afraid of walking alone in Beyoglu (approximately 80\% to 83\%)). There seems to be a slight increase in the rate of women (30\% to $31 \%)$ and men (49.7\% to 51.3\%) who do not fear walking alone and there also seems to be a slight increase in the rate of women who do fear walking alone in 2010 (Figure 5).

When we examine factors which caused insecurity in 2006, we see that participants has chosen other humans 


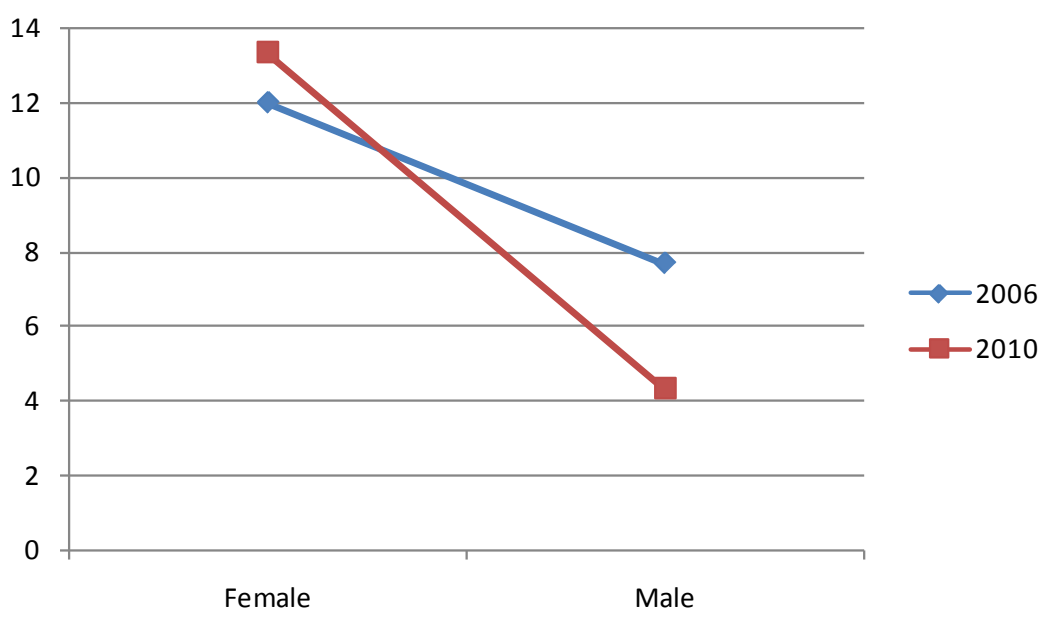

Figure 5. The rate of men and women who fear walking alone.

Table 2. Participants' opinions about environmental safety and fear of crime.

\begin{tabular}{|c|c|c|c|c|}
\hline Safe during Daytime-2006 & Female Frequency & $\%$ of Total & $\begin{array}{c}\text { Male } \\
\text { Frequency }\end{array}$ & \% of Total \\
\hline Safe & 84 & 28.0 & 125 & 41.7 \\
\hline Not safe & 44 & 14.7 & 47 & 15.7 \\
\hline Safe during Daytime-2010 & Female Frequency & $\%$ of Total & $\begin{array}{c}\text { Male } \\
\text { Frequency }\end{array}$ & $\%$ of Total \\
\hline Safe & 108 & 36.0 & 131 & 43.7 \\
\hline Not safe & 25 & 8.3 & 36 & 12.0 \\
\hline Safe during Nighttime-2006 & Female Frequency & $\%$ of Total & $\begin{array}{c}\text { Male } \\
\text { Frequency }\end{array}$ & $\%$ of Total \\
\hline Safe & 21 & 7.0 & 53 & 17.7 \\
\hline Not safe & 107 & 35.7 & 119 & 39.7 \\
\hline Safe during Nighttime- -2010 & Female Frequency & \% of Total & $\begin{array}{c}\text { Male } \\
\text { Frequency }\end{array}$ & $\%$ of Total \\
\hline Safe & 46 & 15.3 & 96 & 32.0 \\
\hline Not safe & 87 & 29.0 & 71 & 23.7 \\
\hline Safe after Renovations - 2006 & Female Frequency & $\%$ of Total & $\begin{array}{c}\text { Male } \\
\text { Frequency }\end{array}$ & $\%$ of Total \\
\hline Safe & 63 & 21.0 & 88 & 29.3 \\
\hline Not safe & 65 & 21.7 & 84 & 28.0 \\
\hline Safe after Renovations-2010 & Female Frequency & $\%$ of Total & $\begin{array}{c}\text { Male } \\
\text { Frequency }\end{array}$ & $\%$ of Total \\
\hline Safe & 44 & 14.7 & 96 & 32.0 \\
\hline Not safe & 89 & 29.7 & 68 & 22.7 \\
\hline Fear of Walking Alone-2006 & Female Frequency & $\%$ of Total & $\begin{array}{c}\text { Male } \\
\text { Frequency }\end{array}$ & $\%$ of Total \\
\hline Yes & 36 & 12.0 & 23 & 7.7 \\
\hline No & 92 & 30.7 & 149 & 49.7 \\
\hline Fear of Walking Alone-2010 & Female Frequency & \% of Total & $\begin{array}{c}\text { Male } \\
\text { Frequency }\end{array}$ & $\%$ of Total \\
\hline Yes & 40 & 13.3 & 13 & 4.3 \\
\hline No & 93 & 31.0 & 154 & 51.3 \\
\hline
\end{tabular}


at only $8.3 \%$ in order of priority, which decreases to be $7.3 \%$ in 2010 . On the other hand, as can be seen in the table below, whereas the most effective factors that cause insecurity are users, urban decay, and poor lighting in 2006, these rates decrease in 2010 after renovations and restoration which took place in the district (Table 3).

In terms of whether or not Beyoglu has become a safe place after the renovations, it is seen that the rate of participants with a negative view is high in 2006, whereas this rate is $44.3 \%$ in 2010 , which is a clear decrease.

When we examine if Beyoglu is safe after the district was renovated, it is seen that $50.3 \%$ of the participants state that it is safe in 2006, but this rate decreases to $37.5 \%$ in 2010 .

Regarding the reasons why Beyoglu is safe or not safe after the renovation of the district, negative views about the area is $48.7 \%$ in 2006, and $44.3 \%$ in 2010 (Figure 6).

Streets where women feel unsafe can be seen below:

The streets women feel unsafe in

- are especially preferred by low income class, and the national/international migrant population. Eg. Tarlabasi, etc.

- are dark and more desolate backstreets. Eg. Arslanyatagi, Sadri Alisik etc.

- are main streets and crowded streets Eg. Tarlabasi, Istiklal, etc.

- have steep slopes enabling the criminal to run away easily. Eg. Meclisi Mebusan

\subsection{Correlation Analysis}

The correlation analysis has shown that gender is (Table 4);

- negatively and significantly correlated with Fear of Walking Alone (2006 and 2010), frequency of use of Beyoglu (2010), Reason for visiting Beyoglu (2010), and negatively correlated with frequency of use of Beyoglu (2006),

Table 3. Factors that create insecurity according to priority.

\begin{tabular}{ccccc}
\hline \multicolumn{2}{c}{$\mathbf{2 0 0 6}$} & \multicolumn{2}{c}{$\mathbf{2 0 1 0}$} \\
Survey Year & Number of People & $\%$ & Number of People & $\%$ \\
Humans & 25 & 8.3 & 22 & 7.3 \\
Users & 134 & 44.7 & 7 & 2.3 \\
Urban Decay & 125 & 41.7 & 16 & 5.3 \\
Poor Lighting & 150 & 50.0 & 81 & 27.0 \\
Unemployment & 122 & 40.7 & 83 & 27.7 \\
\hline
\end{tabular}

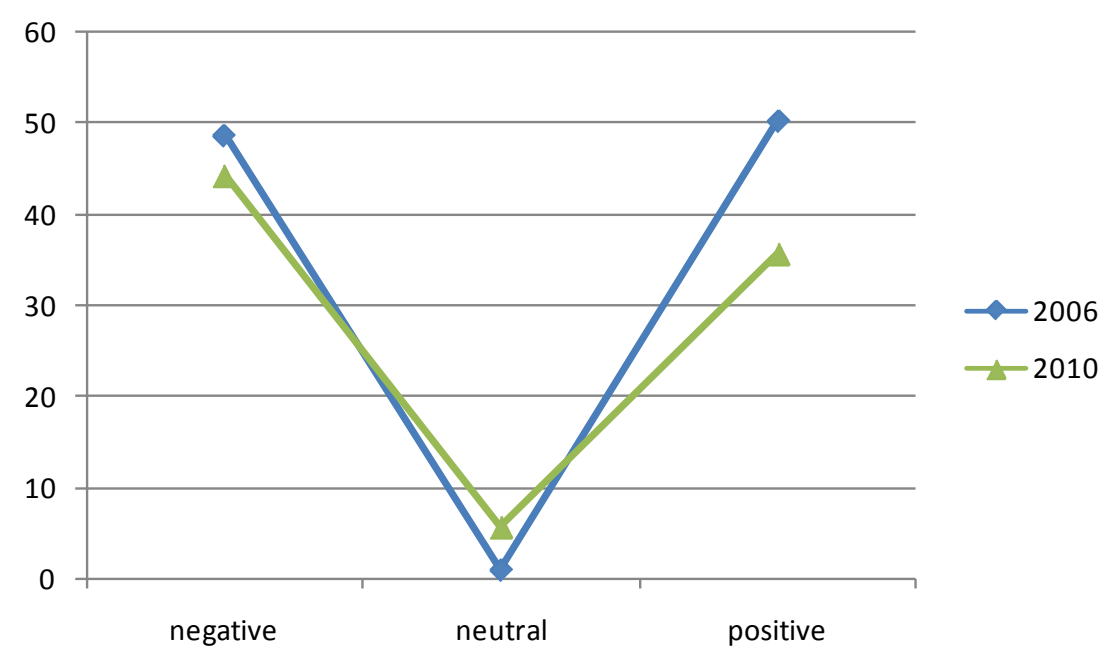

Figure 6. Safety after restoration. 
Table 4. Correlation analysis according to gender.

\begin{tabular}{|c|c|c|c|c|}
\hline \multirow{3}{*}{$\begin{array}{l}\text { Fear of Crime, Environmental Security, Reasons } \\
\text { for Visiting Beyoglu, and Characteristics }\end{array}$} & \multicolumn{4}{|c|}{ Gender } \\
\hline & \multicolumn{2}{|l|}{2006} & \multicolumn{2}{|r|}{2010} \\
\hline & Pearson Correlation & Sig. (2-tailed) & Pearson Correlation & $\begin{array}{c}\text { Sig. } \\
\text { (2-tailed) }\end{array}$ \\
\hline Fear of Walking Alone & $-0.184^{* *}$ & 0.001 & $-0.290^{* *}$ & 0.000 \\
\hline Environmental Safety Daytime & 0.076 & 0.190 & -0.034 & 0.557 \\
\hline Environmental Safety Nighttime & $0.165^{* *}$ & 0.004 & $0.228^{* *}$ & 0.000 \\
\hline Safe after Renovations & 0.019 & 0.740 & $0.254^{* *}$ & 0.000 \\
\hline Safety after renovations_-Reason & 0.052 & 0.372 & $0.159^{*}$ & 0.010 \\
\hline Reason for Visiting Beyoglu & -0.088 & 0.129 & $-0.329^{* *}$ & 0.000 \\
\hline Frequency of use of Beyoglu & $-0.117^{*}$ & 0.043 & $-0.365^{* *}$ & 0.000 \\
\hline
\end{tabular}

${ }^{* *}$ Correlation is significant at the 0.01 level (2-tailed). ${ }^{*}$ Correlation is significant at the 0.05 level (2-tailed).

- positively and significantly correlated with Nighttime Environmental Safety (2006 and 2010), and

- positively correlated with the district's becoming safe after renovations (2010).

\subsection{Regression Analysis}

Multiple linear regression analysis is a type of analysis that aims to estimate the dependent variable based on two or more independent variables that are related to dependent variables. Multiple regression analysis enables researchers to interpret the statistical significance of independent variables and the direction of the relationship between independent variables and the dependent variable.

According to the regression analysis, done based on 2010 data, the dependent variables were determined to be fear of walking alone in Beyoglu. The independent variables were determined to be educational level, occupation, the place of residence, the place of birth, gender, the duration of residence in Istanbul, and age groups. The analysis yielded the following findings (Table 5).

$$
Y=a+b 1 \times 1+b 2 \times 2+b 3 \times 3+\cdots+b n \times n
$$

Life Satisfaction $=2231+0.010 \times$ place of residence $+0.067 \times$ educational level $-0.267 \times$ gender $-0.028 \times$ duration of residence in Istanbul $-0.012 \times$ age groups $-0.019 \times$ place of birth.

There is a significant correlation between fear of walking alone in Beyoglu and gender, occupation, educational level, place of residence, place of birth, duration of residence in Istanbul, age groups $(\mathrm{R}=0.391 \mathrm{R} 2=$ $0.153 p=0.000$ ).

As far as the dependent variable, fear of walking alone in Beyoglu, is concerned, it was found that;

- it is inversely and significantly correlated with gender variable and women fear walking alone more than men,

- it is directly proportional and significantly correlated with educational level variable; fear of walking alone increases as the level of education increases.

\section{Results and Discussion}

Improving the quality of life in big cities is one of the hottest issues of our day and high crime rates in urban areas are one of the things that impair the quality of life in big cities. In order to be able to create healthy living environments, reducing fear of crime is essential, as well as preventing and reducing crime itself. This study examined the old city center, Beyoglu, where crime rates were high and decreased after the renovation process.

As is suggested by Crowe (2000), "Good urban design and effective use of the built-up environment can help reducing fear and repeat of crime and improving environmental quality". 
Table 5. Regression analysis of gender in 2010.

\begin{tabular}{ccccccc}
\hline Regression Analysis & \multicolumn{2}{c}{$\begin{array}{c}\text { Unstandardized } \\
\text { Coefficients }\end{array}$} & $\begin{array}{c}\text { Standardized } \\
\text { Coefficients }\end{array}$ & T & Sig. \\
\hline & B & Std. Error & Beta & & \\
\hline & Dependent Variable: Walking Alone in Beyoglu & & & \\
\hline (Constant) & 2.231 & 0.171 & & 13.023 & 0.000 \\
Gender & -0.267 & 0.046 & -0.347 & -5.846 & 0.000 \\
Occupation & -0.011 & 0.007 & -0.102 & -1.587 & 0.114 \\
Duration of Residence in Istanbul & -0.028 & 0.020 & -0.103 & -1.383 & 0.168 \\
Place of Residence & 0.010 & 0.020 & 0.027 & 0.494 & 0.622 \\
Age Groups & -0.012 & 0.025 & -0.036 & -0.478 & 0.633 \\
Place of Birth & -0.019 & 0.011 & -0.111 & -1.763 & 0.079 \\
Educational Level & 0.067 & 0.027 & 0.158 & 2.464 & 0.014 \\
\hline
\end{tabular}

$\mathrm{R}=0.391 ; \mathrm{R} 2=0.153 ; \mathrm{F}=7.497 ; p=0.000$.

Table 6. The changes in factors according to gender in Beyoglu between 2006 and 2010.

\begin{tabular}{ccc}
\hline The Changes in Factors in Beyoglu between $\mathbf{2 0 0 6}$ and $\mathbf{2 0 1 0}$ & Male & Female \\
Reason for Visiting Beyoglu & For Business Increased & $\begin{array}{c}\text { For Entertainment or Shopping } \\
\text { Increased } \\
\text { The Rate of Daily Visits to Beyoglu }\end{array}$ \\
The Rate of People Who Thinks Beyoglu Is Safe during Daytime & Decreased \\
The Rate of People Who Thinks Beyoglu Is Safe during Nighttime & Increased & Increased \\
The rate of People Who Thinks the district Is Safe after Renovations & Increased & Decreased \\
The Rate of People Who Fear Walking Alone & Decreased & Increased
\end{tabular}

This study has found that fear of crime differs according to gender and similar to the findings of McMillan et al. (2000), McCrea et al. (2005), Chui et al. (2013), that women fear crime more than men. The fear still persists, although it slightly decreased after the renovations, which made the district safer.

The differences in fear of crime in Beyoglu between 2006 and 2010 according to gender; the changes in the rates of fear of crime in men and women according to various factors are given in the table (Table 6).

As can be seen in the table:

- Women come to Beyoglu for shopping and entertainment purposes and this rate increased in 2010,

- The rate of visiting Beyoglu for both men and women decreased in 2010,

- The rate of those who think Beyoglu is safe during daytime increased for both genders,

- The rate of those who think Beyoglu is safe during nighttime increased for both genders,

- The rate of women who thinks the district is safe after the renovations decreased, and

- The rate of women who fear walking alone increased.

As a result of the study, it was found that women, compared to men;

- still feel unsafe after the renovations in the district, and

- fear walking alone.

Prevention of crime and fear of crime is a comprehensive concept which involves law, order, social and educational policies, and built-up urban environment. Therefore, it is apparent that the issue should be handled through a holistic planning approach and through appropriate use of urban design resources.

It is suggested that, in decreasing crime rates and fear of crime, the characteristics of physical environment are more important than demographic characteristics. In her study, which collected survey data from pedestrians before and after street lighting, Painter (1996) suggests that street lighting decreases crime and fear of crime. Thomas (2000) points to the fact that it has a negative effect on fear of crime that employees and officials leave city centers after 17.00 and posits that creating city centers that do not sleep 24 hours would contribute positive- 
ly to the prevention of fear of crime.

Similarly, this study found that in Beyoglu desolate and dark streets are the areas where crime occurs mostly, and therefore, where the rate of fear of crime is the highest (Yirmibesoglu \& Ergun, 2013). Hence, as is stated by Crowe (2000), an appropriate urban design and effective use of built-up environment will decrease fear of crime and repeat of crime, and improve environmental quality.

\section{References}

Berkoz, L., Yirmibesoglu, F., Ertekin, O., \& Baral, K. I. (2013). Mahalle Ölçeğinde Yaşlı Sosyal Hizmet Merkezleri Mekansal Modeli. İTÜ Bilimsel Araştırma Projeleri, 36102 No’lu BAP Projesi.

Chui, W. H., Cheng, K. K.-Y., \& Wong, L.-P. (2013). Gender, Fear of Crime, and Attitudes Toward Prisoners among Social Work Majors in a Hong Kong University. International Journal of Offender Therapy and Comparative Criminology, 57, 479-494.

Crowe, T. D. (2000). Crime Prevention Through Environmental Design. Oxford: Butterworth - Heinemann.

Ergun, N. (2004). Gentrification in Istanbul. Cities, 21, 391-405. http://dx.doi.org/10.1016/j.cities.2004.07.004

Ergun, N., \& Yirmibesoglu, F. (2007). Distribution of Crime Rates in Different Districts in Istanbul. Turkish Studies, 8, 435-455.

Gilchrist, E., Bannister, J., Ditton, J., \& Farrall, S. (1998). Women and the "Fear of Crime": Challenging the Accepted Stereotype. The British Journal of Criminology, 38, 283-298

Gray, E., Jackson, J., \& Farrall, S. (2011). Feelings and Functions in the Fear of Crime, Applying a New Approach to Victimisation Insecurity. British Journal of Criminology, 51, 75-94. http://dx.doi.org/10.1093/bjc/azq066

Hirtenlehner, H., \& Farrall, S. (2013). Anxieties about Modernization, Concerns about Community, and Fear of Crime: Testing Two Related Models. International Criminal Justice Review, 23, 5-24.

http://dx.doi.org/10.1177/1057567712475307

IPD (2008). Istanbul Police Department.

Macmillan, R., Nierobisz, A., \& Welsh, S. (2000). Experiencing the Streets: Harassment and Perceptions of Safety among Women. Journal of Research in Crime and Delinquency, 37, 306-322. http://dx.doi.org/10.1177/0022427800037003003

McCrea, R., Shyy, T., Western, J., \& Stimson, R. J. (2005). Fear of Crime in Brisbane, Individual, Social and Neighbourhood Factors in Perspective. Journal of Sociology, The Australian Sociological Association, 41, 7-27. http://dx.doi.org/10.1177/1440783305048381

Pain, R. H. (1997). Social Geographies of Women's Fear of Crime. Transactions of the Institute of British Geographers, 22, 231-244.

Painter, K. (1996). The İnfluence of Street Lighting İmprovements on Crime, Fear and Pedestrian Street Use, after Dark. Landscape and Urban Planning, 35, 193-201. http://dx.doi.org/10.1016/0169-2046(96)00311-8

Park, R., \& Burgess, E. (1924). Introduction to the Science of Sociology. Chicago, IL: University of Chicago Press.

Rengifo, A. F., \& Bolton, A. (2012) Routine Activities and Fear of Crime: Specifying İndividual-Level Mechanisms. European Journal of Criminology, 9, 99-119. http://dx.doi.org/10.1177/1477370811421648

Schweitzer, J. H., Kim, J. W., \& Mackin, J. R. (1999). The Impact of the Built Environment on Crime and Fear of Crime in Urban Neighborhoods. Journal of Urban Technology, 6, 59-73. http://dx.doi.org/10.1080/10630739983588

Shaw, C., \& McKay, H. (1942). Juvenile Delinquency and Urban Areas. Chicago, IL: University of Chicago Press.

Smith, W., \& Torstensson, M. (1997). Gender Differences in Risk Perception and Neutralizing Fear of Crime: Toward Resolving the Paradoxes. The British Journal of Criminology, 37, 608-634. http://dx.doi.org/10.1093/oxfordjournals.bjc.a014201

Taylor, R. B., \& Covington, J. (1993). Community Structure Change and Fear of Crime. Social Problems, 40, 374-395. http://dx.doi.org/10.2307/3096886

Taylor, R. B., \& Gottfredson, S. (1987). In A. J. Reiss, \& M. Tonry (Eds.), Environmental Design, Crime, and Prevention, Communities and Crime (pp. 403-407). Chicago, IL: The University of Chicago Press.

Thomas, C. J., \& Bromley, R. D. F. (2000). City-Centre Revitalisation: Problems of Fragmentation and Fear in the Evening and Night-Time City. Urban Studies, 37, 1403-1429. http://dx.doi.org/10.1080/00420980020080181

TUIK (2012). 2012 Address-Based Population Registration System.

Wilson, J. Q., \& Kelling, G. L. (1982). Broken Windows. The Atlantic Monthly, 249, 29-38.

Yirmibesoglu, F., \& Ergun, N. (2007). Property and Personal Crime in Istanbul. European Planning Studies, 15, 339-355. http://dx.doi.org/10.1080/09654310601017067

Yirmibesoglu, F., \& Ergun, N. (2013). Fear of Crime in Beyoglu City Center. Regional Science Inquiry Journal, 5, 75-89. 


\section{Appendix}

Appendix 1. Socio-demographic characteristics of the persons.

\begin{tabular}{|c|c|c|c|c|}
\hline Year & \multicolumn{2}{|c|}{ Number of questionnaire } & \multicolumn{2}{|c|}{$\%$} \\
\hline 2006 & \multicolumn{2}{|c|}{300} & \multicolumn{2}{|c|}{100} \\
\hline 2010 & \multicolumn{2}{|c|}{300} & \multicolumn{2}{|c|}{100} \\
\hline Gender 2006 & \multicolumn{2}{|c|}{ Frequency } & \multicolumn{2}{|c|}{$\%$} \\
\hline Female & \multicolumn{2}{|c|}{128} & \multicolumn{2}{|c|}{42.7} \\
\hline Male & \multicolumn{2}{|c|}{172} & \multicolumn{2}{|c|}{57.3} \\
\hline Gender 2010 & \multicolumn{2}{|c|}{ Frequency } & \multicolumn{2}{|c|}{$\%$} \\
\hline Female & \multicolumn{2}{|c|}{133} & \multicolumn{2}{|c|}{44.3} \\
\hline Male & \multicolumn{2}{|c|}{167} & \multicolumn{2}{|c|}{55.7} \\
\hline Age of People 2006 & Female Frequency & $\%$ of Total & $\begin{array}{c}\text { Male } \\
\text { Frequency }\end{array}$ & \% of Total \\
\hline $20<$ & 15 & 5.0 & 10 & 3.3 \\
\hline $21-30$ & 63 & 21.0 & 70 & 23.3 \\
\hline $31-40$ & 36 & 12.0 & 52 & 17.3 \\
\hline $41-50$ & 8 & 2.7 & 26 & 8.7 \\
\hline $51-60$ & 5 & 1.7 & 12 & 4.0 \\
\hline $61+$ & 1 & 0.3 & 2 & 0.7 \\
\hline Age of People 2010 & Female Frequency & $\%$ of Total & $\begin{array}{c}\text { Male } \\
\text { Frequency }\end{array}$ & $\%$ of Total \\
\hline $20<$ & 23 & 7.7 & 21 & 7.0 \\
\hline $21-30$ & 66 & 22.0 & 62 & 20.7 \\
\hline $31-40$ & 26 & 8.7 & 49 & 16.3 \\
\hline $41-50$ & 11 & 3.7 & 22 & 7.3 \\
\hline $51-60$ & 5 & 1.7 & 8 & 2.7 \\
\hline $61+$ & 2 & 0.7 & 5 & 1.7 \\
\hline Level of Education 2006 & Female Frequency & $\%$ of Total & $\begin{array}{c}\text { Male } \\
\text { Frequency }\end{array}$ & $\%$ of Total \\
\hline Primary school & 2 & 0.7 & 19 & 6.3 \\
\hline Secondary school & 17 & 5.7 & 42 & 14.0 \\
\hline High school & 60 & 20.0 & 69 & 23.0 \\
\hline University & 49 & 16.3 & 42 & 14.0 \\
\hline Level of Education 2010 & Female Frequency & $\%$ of Total & $\begin{array}{c}\text { Male } \\
\text { Frequency }\end{array}$ & $\%$ of Total \\
\hline Primary school & 7 & 2.3 & 23 & 7.7 \\
\hline Secondary school & 10 & 3.3 & 29 & 9.7 \\
\hline High school & 64 & 21.3 & 80 & 26.7 \\
\hline University & 52 & 17.3 & 35 & 11.7 \\
\hline
\end{tabular}


Appendix 2. Participants’ place and duration of residence in Istanbul.

\begin{tabular}{|c|c|c|c|c|}
\hline The Duration of Residence in Istanbul 2006 & Female Frequency & $\%$ of Total & $\begin{array}{c}\text { Male } \\
\text { Frequency }\end{array}$ & $\%$ of Total \\
\hline $0-5$ & 17 & 5.7 & 24 & 8.0 \\
\hline $5-10$ & 15 & 5.0 & 12 & 4.0 \\
\hline $10-20$ & 25 & 8.3 & 31 & 10.3 \\
\hline $20-30$ & 43 & 14.3 & 56 & 18.7 \\
\hline $30-40$ & 24 & 8.0 & 33 & 11.0 \\
\hline $40+$ & 4 & 1.3 & 16 & 5.3 \\
\hline The Duration of Residence in Istanbul 2010 & Female Frequency & $\%$ of Total & $\begin{array}{c}\text { Male } \\
\text { Frequency }\end{array}$ & \% of Total \\
\hline $0-5$ & 36 & 12.0 & 28 & 9.3 \\
\hline $5-10$ & 29 & 9.7 & 15 & 5.0 \\
\hline $10-20$ & 37 & 12.3 & 60 & 20.0 \\
\hline $20-30$ & 18 & 6.0 & 37 & 12.3 \\
\hline $30-40$ & 5 & 1.7 & 19 & 6.3 \\
\hline $40+$ & 8 & 2.7 & 8 & 2.7 \\
\hline Place of residence in İstanbul—2006 & Female Frequency & $\%$ of Total & $\begin{array}{c}\text { Male } \\
\text { Frequency }\end{array}$ & $\%$ of Total \\
\hline City Center & 49 & 16.3 & 91 & 30.3 \\
\hline Within 10 km & 49 & 16.3 & 40 & 13.3 \\
\hline $10-20 \mathrm{~km}$ & 25 & 8.3 & 30 & 10.0 \\
\hline $20-30 \mathrm{~km}$ & 4 & 1.3 & 6 & 2.0 \\
\hline 30 and more & 1 & 0.3 & 2 & 0.7 \\
\hline Out of Istanbul & 0 & 0.0 & 3 & 1.0 \\
\hline Place of residence in İstanbul—2010 & Female Frequency & $\%$ of Total & $\begin{array}{c}\text { Male } \\
\text { Frequency }\end{array}$ & $\%$ of Total \\
\hline City Center & 16 & 5.3 & 39 & 13.0 \\
\hline Within 10 km & 73 & 24.3 & 61 & 20.3 \\
\hline $10-20 \mathrm{~km}$ & 27 & 9.0 & 41 & 13.7 \\
\hline $20-30 \mathrm{~km}$ & 13 & 4.3 & 17 & 5.7 \\
\hline 30 and more & 4 & 1.3 & 7 & 2.3 \\
\hline Out of Istanbul & 0 & 0.0 & 1 & 0.3 \\
\hline
\end{tabular}

Appendix 3. Participants’ reasons for visiting Beyoglu and the frequency of visit.

\begin{tabular}{|c|c|c|c|c|}
\hline Reasons for Visiting Beyoglu-2006 & Female Frequency & \% of Total & $\begin{array}{c}\text { Male } \\
\text { Frequency }\end{array}$ & $\%$ of Total \\
\hline Entertainment. shopping & 51 & 17.0 & 45 & 15.0 \\
\hline Business & 30 & 10.0 & 62 & 20.7 \\
\hline Residence & 47 & 15.7 & 65 & 21.7 \\
\hline Reasons for Visiting Beyoglu-2010 & Female Frequency & \% of Total & $\begin{array}{c}\text { Male } \\
\text { Frequency }\end{array}$ & $\%$ of Total \\
\hline Entertainment. shopping & 111 & 37.0 & 78 & 26.0 \\
\hline Business & 17 & 5.7 & 80 & 26.7 \\
\hline
\end{tabular}


F. Yirmibesoglu, N. Ergun

\begin{tabular}{cccccc}
\hline Continued & & & & \\
\hline Residence & 5 & 1.7 & 9 & 3.0 \\
\hline Weekly Use of Beyoglu 2006 & Female Frequency & \% of Total & $\begin{array}{c}\text { Male } \\
\text { Frequency }\end{array}$ & \% of Total \\
\hline Seldom & 15 & 5.0 & 17 & 5.7 & 5.0 \\
$1-2$ & 23 & 7.7 & 15 & 4.7 & 13.7 \\
$3-4$ & 12 & 4.0 & 14 & 28.3 \\
\hline $5-6$ & 25 & 8.3 & 85 & \% of Total \\
\hline Everyday & 53 & 17.7 & Male & 10.7 \\
\hline Seldom & Female Frequency & \% of Total & 32 & 9.3 \\
\hline Eve of Beyoglu 2010 -4 & 50 & 38 & 16.7 & 28 & 8.3 \\
\hline
\end{tabular}

